\title{
PENGARUH TINGKAT KEDISIPLINAN DAN TANGGUNG JAWAB KARYAWAN TERHADAP PRODUKTIVITAS KERJA DI PT KAWAI PIANO INDONESIA
}

\author{
N. Neni Triana ${ }^{1}$, Ahmad Hilmi Insani ${ }^{2}$ \\ 1,2Jurusan Teknik Industri, Fakultas Teknik dan Ilmu Komputer, Universitas Buana Perjuangan Karawang \\ Jl. HS. Ronggowaluyo Telukjambe Timur Karawang, \\ Email: neni.triana@ubpkarawang.ac.id
}

\begin{abstract}
There are many factors that affect productivity including the number of hours worked, quality of work, morale, work discipline, efficiency and effectiveness of work. The purpose of the study was to determine the effect of work discipline and responsibility on work productivity at PT. Kawai Piano Indonesia. The population of this study were all employees of PT. Kawai Piano Indonesia, with an error rate of 5\% with a sample of 100 employees. The quantitative research method uses linear regression with SPSS 25. The results of the study at a significance level of 5\% indicate that: (1) There is a simultaneous influence of discipline in company discipline and discipline in work responsibilities on work productivity at PT. Kawai Piano Indonesia. This is evidenced in the ANOVA table, the value of $f$-count $>$ f-table (60.688 > 3.09) is obtained. (2) There is the ability of the independent variable, namely discipline in company regulations and discipline in responsibility at work in explaining variations in changes in the productivity dependent variable, which is $54.7 \%$, while the remaining $45.3 \%$ is explained by other factors.
\end{abstract}

Keywords: multiple linear regression analysis; discipline; work productivity; responsible.

\begin{abstract}
ABSTRAK
Sumber daya manusia atau dikenal sebagai karyawan memiliki peran penting dalam menentukan keberhasilan dan pencapaian tujuan perusahaan sehingga perusahaan berupaya untuk mendapatkan karyawan yang dapat memberikan prestasi kerja dalam bentuk produktivitas kerja setinggi mungkin untuk mewujudkan tujuan yang telah ditetapkan sebelumnya. Terdapat banyak faktor yang mempengaruhi produktivitas di antaranya jumlah jam kerja, mutu pekerjaan, semangat kerja, disiplin kerja, efisiensi dan efektivitas pekerjaan. Tujuan penelitian adalah untuk mengetahui pengaruh disiplin kerja dan tanggung jawab terhadap produktivitas kerja pada PT. Kawai Piano Indonesia. Populasi dari penelitian ini adalah seluruh karyawan PT. Kawai Piano Indonesia, dengan tingkat kesalahan 5\% dengan sampel 100 karyawan. Metode penelitian kuantitatif menggunakan regresi linear dengan SPSS 25. Hasil penelitian pada taraf signifikansi 5\% menunjukkan bahwa : (1) Terdapat pengaruh secara simultan disiplin dalam tata tertib perusahaan dan disiplin dalam tanggung jawab pada pekerjaan terhadap produktivitas kerja di PT. Kawai Piano Indonesia. Hal ini dibuktikan pada tabel ANOVA diperoleh nilai f-hitung > f-tabel (60.688 > 3.09). (2) Terdapat kemampuan variabel independen yaitu disiplin dalam tata tertib perusahaan dan disiplin dalam tanggung jawab pada pekerjaan dalam menerangkan variasi perubahan variabel dependen produktivitas yaitu sebesar 54,7\%, sedangkan sisanya sebesar 45,3\% diterangkan oleh faktor-faktor lain.
\end{abstract}

Kata kunci: analisis regresi linier berganda; kedisplinan; produktivitas kerja; tanggung jawab

\section{PENDAHULUAN}

Sumber daya manusia atau dikenal sebagai karyawan memiliki peran penting dalam menentukan keberhasilan dan pencapaian tujuan perusahaan. Dalam rangka pencapaian tujuan tersebut, sumber daya selalu dituntut untuk mampu meningkatkan produktivitas kerjanya demi kelangsungan dan peningkatan kinerja, pendapatan dan keuntungan perusahaan. Menurut Hasibuan 
(2011) Karyawan merupakan "salah satu kunci sukses dari berdirinya sebuah organisasi. Peran vitalnya didalam organisasi atau perusahaan dapat menentukan kemana arah perusahaan tersebut akan berlayar dan juga sebagai alat penentu keberhasilan perusahaan dalam jangka waktu tertentu." Disiplin karyawan juga merupakan pengendali operasi perusahaan, sehingga jika kedisiplinan karyawan baik maka target perusahaan akan tercapai, sebaliknya jika kedisiplinan karyawan menurun maka target perusahaan juga akan tida terapcapai.

Perusahaan berupaya untuk mendapatkan karyawan yang dapat memberikan prestasi kerja dalam bentuk produktivitas kerja setinggi mungkin untuk mewujudkan tujuan yang telah ditetapkan sebelumnya. Terdapat banyak faktor yang dapat mempengaruhi produktivitas diantaranya jumlah jam kerja, mutu pekerjaan, semangat kerja, disiplin kerja, efisiensi dan efektivitas pekerjaan dan lain-lain. Maka dari itu untuk mencapai produktivitas yang tinggi pimpinan perusahaan hendaknya harus memperhatikan salah satu faktor yang mempengaruhinya antara lain adalah disiplin kerja yaitu sikap mental yang mampu memberikan dorongan bagi seseorang untuk dapat bekerja lebih giat, cepat, dan baik. Kinerja karyawan yang tinggi akan berpengaruh terhadap efisiensi kerja dan efektivitas kerja.

Tabel 1. Data Absensi Karyawan PT. Kawai Piano Indonesia 2018

\begin{tabular}{clcccc}
\hline P1 & Bulan & $\begin{array}{c}\text { Jumlah } \\
\text { Karyawan }\end{array}$ & $\begin{array}{c}\text { Hari } \\
\text { Kerja }\end{array}$ & $\begin{array}{c}\text { Jumlah } \\
\text { Absensi }\end{array}$ & $\begin{array}{c}\text { Tingkat } \\
\text { Absensi \% }\end{array}$ \\
\hline 1 & Januari & 277 & 22 & 11 & $0.18 \%$ \\
2 & Februari & 278 & 20 & 8 & $0.14 \%$ \\
3 & Maret & 278 & 22 & 2 & $0.03 \%$ \\
4 & April & 278 & 21 & 14 & $0.24 \%$ \\
5 & Mei & 278 & 21 & 11 & $0.19 \%$ \\
6 & Juni & 280 & 13 & 21 & $0.58 \%$ \\
7 & Juli & 280 & 23 & 10 & $0.16 \%$ \\
8 & Agustus & 278 & 21 & 15 & $0.26 \%$ \\
9 & September & 278 & 19 & 22 & $0.42 \%$ \\
10 & Oktober & 280 & 23 & 15 & $0.23 \%$ \\
11 & November & 280 & 20 & 19 & $0.34 \%$ \\
12 & Desember & 280 & 10 & 22 & $0.79 \%$ \\
& Rata-rata & $\mathbf{2 7 9}$ & $\mathbf{1 9 . 6}$ & $\mathbf{1 4 . 2}$ & $\mathbf{0 . 3 0 \%}$ \\
\hline
\end{tabular}

\section{Sumber: Perusahaan}

Berdasarkan Tabel di atas dapat dilihat bahwa banyaknya karyawan yang masih merasa kurang disiplin dalam bekerja. Persentase ketidakhadiran paling buruk pada bulan Juni, September, November, dan Desember, karena bertepatan dengan hari besar keagamaan dan libur akhir tahun, sehingga karyawan banyak yang tidak hadir untuk bekerja. Berdasarkan paparan di atas, masalah yang terjadi pada PT. Kawai Piano Indonesia adalah: (1) Apakah kedisiplinan dalam tata tertib perusahaan dapat mempengaruhi produktivitas kerja di PT. Kawai Piano Indonesia, (2) Apakah Kedisiplinan dalam tanggung jawab pada pekerjaan dapat mempengaruhi produktivitas kerja di PT. Kawai Piano Indonesia.dan (3) Apakah kedisiplinan dalam tata tertib perusahaan dan tanggung jawab pada pekerjaan dapat mempengaruhi produktivitas kerja di PT. Kawai Piano Indonesia. Adapun tujuan penelitian untuk mengetahui apakah ada pengaruh kedisiplinan dalam tata tertib perusahaan terhadap produktivitas kerja di PT. Kawai Piano Indonesi, pengaruh tanggung jawab pada pekerjaan terhadap produktivitas dan pengaruh kedisiplinan dalam tata tertib perusahaan dan tanggung jawab pada pekerjaan terhadap produktivitas kerja di PT. Kawai Piano Indonesia.

\section{TINJAUAN PUSTAKA}

Sumber Daya Manusia

Sumber Daya Manusia (SDM) dalam konteks bisnis merupakan orang yang bekerja dalam suatu organisasi yang sering pula disebut karyawan. SDM merupakan aset paling berharga dalam 
perusahaan, tanpa manusia maka sumber daya perusahaan tidak akan dapat mengahasilkan laba atau menambah nilainya sendiri. Manajemen SDM didasari pada suatu konsep bahwa setiap karyawan adalah manusia, bukan mesin, dan bukan semata menjadi sumber daya bisnis. Manajemen Sumber Daya Manusia - untuk selanjutnya disebut MSDM berkaitan dengan kebijakan dan praktik-praktik yang perlu dilaksanakan oleh manajer, mengenai aspek-aspek SDM dari Manajemen Kerja

\section{Disiplin Kerja}

Menurut Muchadarsyah sinugan dalam Rahmat Hasbullah (2016: 327) disiplin adalah "sikap mental yang tercermin dalam perbuatan atau tingkah laku individu, kelompok, atau masyarakat, berupa ketaatan". Siswanto Sastrohadiwiryo dalam Rahmat Hasbullah (2016: 327) menyatakan bahwa "disiplin kerja dapat didefinisikan sebagai suatu sikap menghormati, menghargai, patuh, dan taat terhadap peraturan-peraturan yang berlaku baik yang tertulis maupun tidak tertulis". Sesuai pendapat Harlie dalam Rahmat Hasbullah (2016: 327) "secara alami, kesadaran diri antara individu-individu pada disiplin kerja harus dikembangkan dalam rangka untuk menyelesaikan tugas-tugas yang diberikan oleh organisasi melalui motivasi pengembangan dan komitmen dari orang-orang dalam organisasi”.

\section{Produktivitas}

Definisi dari produktivitas pertama kali muncul pada tahun 1776 dalam sebuah makalah yang disusun dan ditulis oleh Francis Quesnay yang berasal dari Perancis. Menurut Sinungan, $(2007 ; 1)$ dalam " Motivation and Awareness ", "filosofi dan spirit tentang produktivitas sudah ada sejak awal peradaban manusia karena makna produktivitas adalah keinginan (Will) dan upaya (Effort) manusia untuk selalu meningkatkan kualitas didalam segala bidang". Produktivitas sebagai konsep yang menyatakan bagaimana keluaran akan berubah apabila masukan berubah.

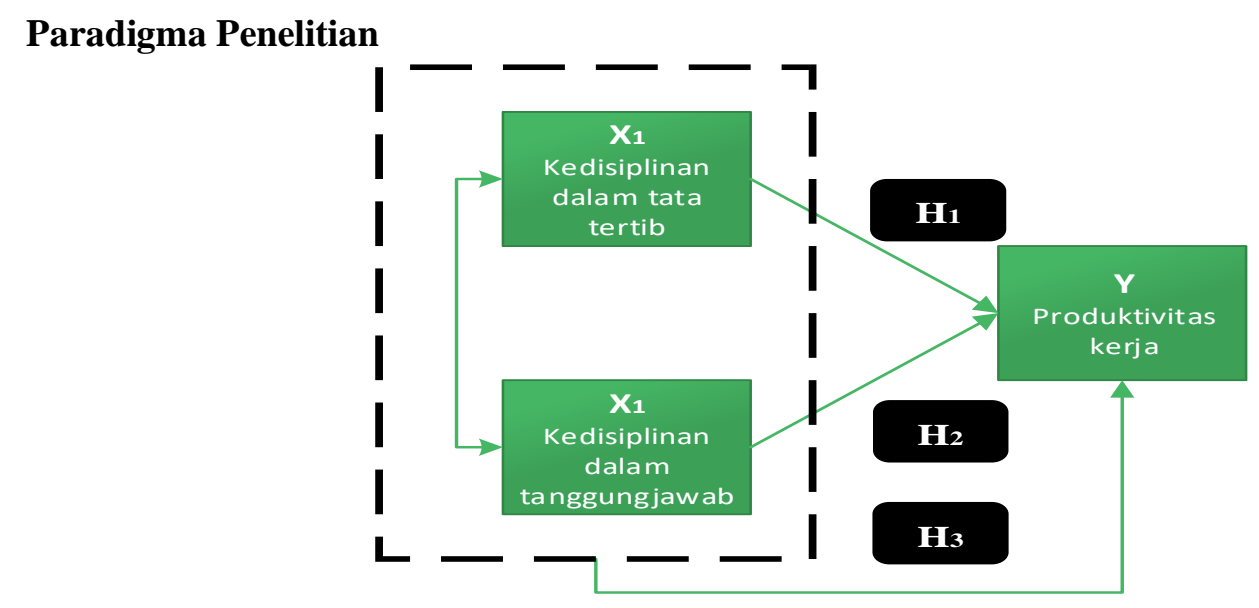

Gambar 1. Kerangka Pemikiran

\section{METODE PENELITIAN}

Penelitian ini termasuk dalam kategori penelitian asosiatif kausal dengan menggunakan pendekatan kuantitatif. Penelitian asosiatif kausal adalah penelitian yang bertujuan untuk mengetahui pengaruh antara dua variabel atau lebih" (Sugiyono, 2012). Penelitian ini akan menjelaskan hubungan mempengaruhi dan dipengaruhi dari variabel-variabel yang akan diteliti, yaitu pengaruh variabel pelatihan dan disiplin kerja terhadap variabel produktivitas kerja karyawan. Pendekatan kuantitatif digunakan karena data yang akan digunakan untuk menganalisis pengaruh antar variabel dinyatakan dengan angka. 


\section{Populasi dan Sampel}

Pada populasi 240 Karyawan, besaran sampel dengan tingkat kesalahan $5 \%$ dengan menggunakan rumus Slovin didapat sampel sebesar 100 sampel dengan taraf kesalahan yang mungkin terjadi tidak lebih dari 0,05 atau $5 \%$.

\section{Teknik Analisis Data \\ Uji Coba Instrumen}

Agar data yang diperoleh dengan kuesioner dapat valid dan reliabel maka perlu dilakukan uji validitas dan reabilitas kuesioner terhadap butir-butir pernyataan sehingga dapat diketahui layak tidaknya untuk pengumpulan data. Uji instrument dilakukan dengan menggunakan teknik repeated measure (pengukuran berulang) dengan menguji item-item pernyataan kepada responden. Kuesioner ini diujicobakan pada 100 orang responden yang termasuk populasi penelitian yakni pada karyawan yang bekerja di PT. Kawai Piano Indonesia. Meskipun penelitian ini menggunakan kuesioner dari penelitian sebelumnya, akan tetapi penelitian ini tetap perlu melakukan uji coba validitas dan reliabilitas. "Hal ini karena subjek, objek, dan waktu penelitian yang ada pada penelitian saat ini memiliki karakteristik responden yang sama" (Ghozali, 2011:44)

\section{Uji Validitas}

Menurut (Ghozali, 2011) "Uji validitas digunakan untuk mengukur sah atu valid tidaknya suatu kuesioner. Suatu kuesioner dikatakan valid jika pernyataan kuesioner tersebut". Validitas dalam penelitian menyatakan derajat ketepatan alat ukur penelitian terhadap isi atau arti sebenarnya yang diukur.

r - hitung (Corrected Item-Total Correlation) > r - tabel

\section{Uji Reliabilitas}

Reliabilitas adalah "alat ukur mengukur suatu kuesioner yang merupakan indikator dari variable atau konstruksi. Suatu kontruksi dikatakan reliable atau handal jika jawaban seseorang terhadap pertanyaan konsisten atau stabil dari waktu ke waktu" (Ghozali, 2011:47).

Cronbach's Alpha > 0,70

\section{Uji Asumsi Klasik}

Sebelum melakukan uji hipotesis perlu dilakukan uji asumsi klasik terlebih dahulu agar penelitian tidak bias dan untuk menguji kesalahan model regresi yang digunakan dalam penelitian. Menurut Ghozali (2011) "model regresi yang digunakan akan menunjukkan hubungan yang signifikan dan representatif (BLUE $=$ Best Linier Unbiased Estimator) apabila memenuhi asumsi dasar klasik regresi yaitu apabila tidak terjadi gejala"

\section{Uji Normalitas}

Uji normalitas bertujuan untuk "menguji apakah dalam model regresi, variabel pengganggu atau residual memiliki distribusi normal. Seperti diketahui bahwa uji t dan F mengasumsikan bahwa nilai residual mengikuti distribusi normal. Kalau asumsi ini dilanggar maka uji statistik menjadi tidak valid untuk jumlah sampel kecil" (Ghozali, 2011)

nilai Asymp. Sig (2-tailed) < 0,05 berarti berdistribusi normal.

nilai Asymp. Sig (2-tailed) $>0,05$ berarti tidak berdistribusi normal.

\section{Uji Multikolinieritas}

Uji multikoliniearitas bertujuan untuk "menguji apakah model regresi ditemukan adanya korelasi antara variabel bebas (independen). Model regresi yang baik sebaiknya tidak terjadi korelasi di antara variabel independen" (Ghozali, 2011). Salah satu alat untuk mendeteksi ada atau tidaknya multikolinieritas di dalam model regresi adalah dengan melihat nilai tolerance dan lawannya serta nilai Variance Inflation Faktor (VIF).

Jika nilai VIF < 10 maka tidak terjadi Multikolinearitas.

Jika nilai tolerance $<0,1$ maka tidak terjadi Multikolinearitas. 


\section{Uji Heteroskedastisitas}

Menurut Ghozali (2011) "uji heteroskedastisitas bertujuan untuk menguji apakah dalam model regresi terjadi ketidaksamaan varian dari residual untuk semua pengamatan pada model regresi”. Pola yang tidak sama ini ditunjukkan dengan nilai yang tidak sama antar satu varians dari residual.

Jika nilai signifikasi $>0,05$ berarti tidak terjadi heteroskedastisitas

Jika nilai signifikasi $<0,05$ berarti terjadi heteroskedastisitas

\section{Uji Hipotesis}

Uji hipotesis bertujuan untuk mengetahui apakah terdapat pengaruh yang jelas dan dapat dipercaya antara variabel independen (pelatihan dan disiplin kerja) terhadap variabel dependen (produktifitas kerja). Pengujian hipotesis menggunakan uji regresi berganda.

\section{Analisis Regresi Berganda}

"Analisis regresi linier berganda digunakan untuk menganalisa pengaruh beberapa variabel bebas atau independen variabel $(\mathrm{X})$ terhadap satu variabel tidak bebas atau dependen variabel (Y) secara bersama-sama. Dalam hubungan dengan penelitian ini, variabel independen adalah disiplin tata tertib perusahaan ( ) dan Disiplin dalam tanggung jawab bekerja ( ), sedangkan variabel dependen adalah Produktivitas Kerja (Y), sehingga persamaan regresi berganda estimasinya":

Dimana :

$$
\begin{aligned}
\mathrm{Y} & =\text { Produktivitas Kerja } \\
& =\text { Konstanta dari persamaan regresi } \\
\beta & =\text { Koefisien regresi dari variabel , Disiplin dalam tata tertib perusahaan } \\
\beta & =\text { Koefisien regresi dari variabel , Disiplin dalam tanggung jawab bekerja } \\
& =\text { Disiplin dalam tata tertib perusahaan } \\
& =\text { Disiplin dalam tanggung jawab bekerja }
\end{aligned}
$$

\section{Uji t}

Untuk mengetahui apakah hubungan antara variabel bebas mempunyai pengaruh yang nyata atau tidak terhadap variabel terikat, maka dilakukan uji hipotesis. Bentuk pengujiannya adalah sebagai berikut :

$\mathrm{r}=0$; artinya tidak terdapat pengaruh yang signifikan antara variabel predikator ( ) dengan variabel terikat ( ).

$r \neq 0$; artinya ada pengaruh yang signifikan antara variabel predikator ( ) dengan variabel terikat. Selanjutnya untuk mengetahui signifikansi konstanta dari setiap variabel independen terhadap variabel terikat, maka dilakukan Uji t, yang sebagaimana yang dikemukakan oleh Sugiyono (2012). t-hitung > t-tabel

\section{Uji F}

Uji $F$ digunakan untuk mengetahui pengaruh variabel independen secara bersama sama terhadap variabel dependen. F-tes digunakan untuk menguji pengaruh secara bersama-sama antara pendapatan bagi hasil dan beban operasional terhadap laba bersih.

Hipotesis yang akan diuji adalah sebagai berikut: terhadap $\mathrm{Y}$.

$\mathrm{H} 0: \beta 1=\beta 2=0$, maka variabel bebas $\mathrm{X} 1, \mathrm{X} 2$ secara simultan tidak berpengaruh signifikan terhadap Y.

$\mathrm{H} 1: \beta 1 \neq \beta 2 \neq 0$, maka variabel bebas $\mathrm{X} 1, \mathrm{X} 2$ secara simultan berpengaruh signifikan

Jika nilai F-hitung > F-tabel maka secara bersama-sama variabel independen berpengaruh signifikan terhadap variabel dependen atau Ho ditolak. Jika F-hitung < F-tabel maka secara bersama-sama variabel independen tidak berpengaruh signifikan terhadap variabel dependen atau Ho diterima. Atau dapat juga digunakan dengan kriteria pengujian tingkat signifikansi 5\% :

Jika nilai signifikansi F-hitung > 0,05, yang artinya bahwa variabel bebas (X1) secara simultan tidak berpengaruh terhadap variabel dependen. Maka Ho diterima dan Ha ditolak.

Jika nilai signifikansi f-hitung $<0,05$ yang artinya bahwa variabel bebas (X1) secara simultan berpengaruh terhadap variabel terikat. Maka Ho ditolak dan Ha diterima. Nilai signifikansi dari uji F 
dapat dilihat pada hasil pengolahan dari program SPSS pada tabel ANOVA kolom sig atau significance.

\section{Koefisien determinasi $\left(\mathbf{R}^{2}\right)$}

Koefisien determinasi $\left(\mathrm{R}^{2}\right)$ digunakan untuk mengukur seberapa jauh kemampuan model dalam menerangkan variasi variabel dependen.Nilai koefisien determinasi adalah antara 0 dan 1 .

Nilai koefisien determinasi yang kecil berarti kemampuan variabel-variabel independen dalam menjelaskan variasi variabel dependen amat terbatas.Nilai yang mendekati 1 berarti variabel-variabel independen memberikan hampir semua informasi yang dibutuhkan untuk memprediksi variasi variabel dependen (Ghozali, 2018) (Ghozali, 2018). Berarti antara variabel independen dengan variabel terikat mempunyai hubungan kuat.

\section{HASIL DAN PEMBAHASAN}

Analisis Deskriptif

Karakteristik sampel yang digunakan didalam penelitian yang disajikan dalam Tabel berikut:

Tabel 2. Karakteristik Responden Berdasarkan Jenis Kelamin

\begin{tabular}{cccc}
\hline No & Jenis kelamin & $\begin{array}{c}\text { jumlah } \\
\text { responden }\end{array}$ & Persentase \% \\
\hline 1 & laki-laki & 85 & $85 \%$ \\
2 & perempuan & 15 & $15 \%$ \\
& jumlah & $\mathbf{1 0 0}$ & $\mathbf{1 0 0 \%}$ \\
\hline
\end{tabular}

Tabel 3. Karakteristik Responden berdasarkan Usia

\begin{tabular}{cccc}
\hline No & usia & $\begin{array}{c}\text { jumlah } \\
\text { responden }\end{array}$ & Prsentase \% \\
\hline 1 & $<21$ tahun & 5 & $5 \%$ \\
2 & $21-30$ tahun & 50 & $50 \%$ \\
3 & $31-40$ tahun & 43 & $43 \%$ \\
4 & $>40$ tahun & 2 & $2 \%$ \\
& jumlah & $\mathbf{1 0 0}$ & $\mathbf{1 0 0} \%$ \\
\hline
\end{tabular}

Tabel 4. Karakteristik Responden berdasarkan Lama Bekerja

\begin{tabular}{cccc}
\hline No & lama bekerja & $\begin{array}{c}\text { jumlah } \\
\text { responden }\end{array}$ & prsentase \% \\
\hline 1 & $<1$ tahun & 0 & $0 \%$ \\
2 & $1-10$ tahun & 65 & $65 \%$ \\
3 & $10-20$ tahun & 35 & $35 \%$ \\
& total & $\mathbf{1 0 0}$ & $\mathbf{1 0 0} \%$ \\
\hline
\end{tabular}

Tabel tersebut menunjukkan bahwa responden dengan masa kerja kurang dari 1 tahun terdapat 0 karyawan, $1-10$ tahun terdapat 65 karyawan (65\%), dan $10-20$ tahun 35 karyawan (35\%). Tabel tersebut menunjukkan bahwa dominan karyawan bekerja di rentan $1-10$ tahun

\section{Uji Instrumen Data}

\section{Uji Validitas}

Uji Validitas Kuesioner Variabel Disiplin dalam Tata Tertib Perusahaan $\left(\mathrm{X}_{1}\right)$

Berdasarkan hasil perhitungan uji validitas variabel disiplin dalam Tata Tertib Perusahaan $\left(\mathrm{X}_{1}\right)$ dengan 4 item pertanyaan adalah sebagai berikut: 
Tabel 5. Hasil Uji Validitas Disiplin dalam Tata tertib Perusahaan $\left(\mathrm{X}_{1}\right)$

\begin{tabular}{cccccc}
\hline no & variabel & r-hitung & r-tabel & nilai sig & keputusan \\
\hline 1 & $\mathrm{X} 1.1$ & .694 & 0.195 & .000 & VALID \\
2 & $\mathrm{X} 1.2$ & .634 & 0.195 & .000 & VALID \\
3 & $\mathrm{X} 1.3$ & .514 & 0.195 & .000 & VALID \\
4 & $\mathrm{X} 1.4$ & .758 & 0.195 & .000 & VALID \\
5 & $\mathrm{X} 1.5$ & .857 & 0.195 & .000 & VALID \\
6 & $\mathrm{X} 1.6$ & .787 & 0.195 & .000 & VALID \\
7 & $\mathrm{X} 1.7$ & .461 & 0.195 & .000 & VALID \\
8 & $\mathrm{X} 1.8$ & .734 & 0.195 & .000 & VALID \\
9 & $\mathrm{X} 1.9$ & .765 & 0.195 & .000 & VALID \\
\hline
\end{tabular}

Berdasarkan Tabel di atas maka dapat dilihat bahwa seluruh pertanyaan untuk variabel stres individu $\left(\mathrm{X}_{1}\right)$ di nyatakan valid, karena nilai rhitung (Corrected Item-Total Correlation) > rtabel sebesar 0.195 , jadi kesimpulanya semua data $\left(\mathrm{X}_{1}\right)$ valid dan bisa di pakai untuk peguijian selanjutnya.

\section{Uji Validitas Kuesioner Variabel Disiplin dalam Tanggung Jawab Pada Perusahaan $\left(\mathbf{X}_{2}\right)$}

Berdasarkan hasil perhitungan uji validitas variabel Disiplin dalm Tanggung Jawab Pada Perusahaan $\left(\mathrm{X}_{2}\right)$ dengan 4 item pertanyaan adalah sebagai berikut:

Tabel 6. Hasil Uji Validitas Disiplin dalam Tanggung Jawab Pada Perusahaan $\left(\mathrm{X}_{2}\right)$

\begin{tabular}{cccccc}
\hline no & variabel & r-hitung & r-tabel & nilai sig & keputusan \\
\hline 1 & $\mathrm{X} 2.1$ & .790 & 0.195 & .000 & VALID \\
2 & $\mathrm{X} 2.2$ & .831 & 0.195 & .000 & VALID \\
3 & $\mathrm{X} 2.3$ & .790 & 0.195 & .000 & VALID \\
4 & $\mathrm{X} 2.4$ & .610 & 0.195 & .000 & VALID \\
5 & $\mathrm{X} 2.5$ & .733 & 0.195 & .000 & VALID \\
6 & $\mathrm{X} 2.6$ & .712 & 0.195 & .000 & VALID \\
7 & $\mathrm{X} 2.7$ & .741 & 0.195 & .000 & VALID \\
8 & $\mathrm{X} 2.8$ & .777 & 0.195 & .000 & VALID \\
9 & $\mathrm{X} 2.9$ & .513 & 0.195 & .000 & VALID \\
\hline
\end{tabular}

Berdasarkan Tabel di atas maka dapat dilihat bahwa seluruh pertanyaan untuk variabel stres individu $\left(\mathrm{X}_{2}\right)$ di nyatakan valid, karena nilai rhitung (Corrected Item-Total Correlation) > rtabel sebesar 0.195 , jadi kesimpulanya semua data $\left(\mathrm{X}_{2}\right)$ valid dan bisa di pakai untuk peguijian selanjutnya.

\section{Uji Validitas Kuesioner Variabel Produktivitas (Y)}

Berdasarkan hasil perhitungan uji validitas variabel Produktivitas (Y) dengan 3 item pertanyaan adalah sebagai berikut:

Tabel 7. Hasil Uji Validitas Variabel Produktivitas (Y)

\begin{tabular}{llll}
\hline no & variabel & r-hitung & r-tabel \\
\hline 1 & Y1 & .762 & 0.195 \\
2 & Y2 & .790 & 0.195 \\
3 & Y3 & .827 & 0.195 \\
\hline
\end{tabular}

Berdasarkan Tabel di atas maka dapat dilihat bahwa seluruh pertanyaan untuk variabel Kinerja karyawan memiliki status valid, karena nilai rhitung (Corrected Item-Total Correlation) > rtabel sebesar 0.195, jadi kesimpulanya semua data $(\mathrm{Y})$ valid dan bisa di pakai untuk peguijian selanjutnya. 


\section{Uji Reliabilitas}

Berdasarkan ringkasan hasil uji reliabilitas seperti yang terangkum dalam tabel diatas, dapat diketahui bahwa nilai Cronbach Alpha pada masing-masing variabel nilainya lebih besar dari nilai kritis 0,70. Hasil tersebut dapat disimpulkan bahwa seluruh instrumen penelitian dapat dinyatakan reliabel / handal dan dapat digunakan untuk analisis selanjutnya. Artinya kuisioner ini memiliki hasil yang konsisten jika dilakukan pengukuran dalam waktu dan model atau desain yang berbeda.

Tabel 8. Hasil Uji Reliabilitas

\begin{tabular}{|c|c|c|c|c|}
\hline no & variabel & $\begin{array}{l}\text { Nilai } \\
\text { Alfa }\end{array}$ & cronbach & keputusan \\
\hline 1 & $\mathrm{X} 1$ & 0.862 & & RELIABEL \\
\hline 2 & $\mathrm{X} 2$ & 0.909 & & RELIABEL \\
\hline 3 & Y & 0.806 & & RELIABEL \\
\hline
\end{tabular}

\section{Uji Asumsi Klasik}

Uji Normalitas

Hasil uji normalitas, diperoleh disiplin dalam tata tertib perusahaan, disiplin dalam tanggung jawab pekerjaan dan produktivitas kerja dengan nilai Asymp. Sig (2-tailed) sebesar 0,200. Nilai signifikansi dengan besaran 0,200 memiliki nilai yang lebih besar dari taraf signifikani 0,05 $(0,200>$ $0,05)$, dapat disimpulkan bahwa data yang digunakan dalam penelitian berdistribusi dengan normal.

\section{Uji Multikolinieritas}

Jika nilai VIF < 10 maka tidak terjadi Multikolinearitas.

Jika nilai tolerance $<0,1$ maka tidak terjadi Multikolinearitas.

\section{Coefficients $^{\mathrm{a}}$}

Tabel 9. Hasil Uji Multikolinearitas

\begin{tabular}{ll|l|l|l|l|l|l|}
\multicolumn{3}{c}{} & \multicolumn{2}{l}{$\begin{array}{l}\text { Unstandardized } \\
\text { Coefficients }\end{array}$} & $\begin{array}{l}\text { Standardized } \\
\text { Coefficients }\end{array}$ & & \multicolumn{3}{c}{$\begin{array}{l}\text { Collinearity } \\
\text { Statistics } \\
\text { Model }\end{array}$} & $\mathrm{B}$ & Std. Error & Beta & $\mathrm{t}$ & Sig. & Tolerance & VIF \\
\hline 1 (Constant) & -2.215 & 1.294 & & - & .090 & & \\
\hline $\mathrm{X} 1$ & .302 & .041 & .534 & 1.712 & & \\
\hline $\mathrm{X} 2$ & .168 & .034 & .356 & 7.311 & .000 & .857 & 1.167 \\
\hline
\end{tabular}

Nilai Tolerance dari disiplin terhadap peraturan perusahaan $\left(X_{1}\right)$ dan disiplin terhadap tanggung jawab pekerjaan $\left(X_{2}\right)$ diperoleh sebesar 0,857 yang artinya nilai Tolerance $>0,10(0,857>$ $0,10)$. Sehingga dapat dikatakan bahwa model regresi dalam penelitian ini terbebas dari gejala multikolinearitas.

\section{Uji Heteroskedastisitas}

Berdasarkan hasil pengujian, diperoleh bahwa nilai signifikasi dari disiplin terhadap peraturan perusahaan $\left(\mathrm{X}_{1}\right)$ yaitu $(0.280>0.05)$ dan disiplin terhadap tanggung jawab pekerjaan $(\mathrm{X} 2)$ yaitu (0.095 > 0.05). Maka dengan demikian dapat di simpulkan bahwa tidak terjadi masalah heteroskedastisitas pada model regresi ini.

\section{Coefficients $^{\mathrm{a}}$}

\section{Tabel 10. Hasil Uji Heteroskedastisitas}

\begin{tabular}{|c|c|c|c|c|c|c|}
\hline \multirow[b]{2}{*}{ Model } & & \multicolumn{2}{|c|}{ Unstandardized Coefficients } & \multirow{2}{*}{$\begin{array}{l}\text { Standardized } \\
\text { Coefficients } \\
\text { Beta }\end{array}$} & \multirow[b]{2}{*}{$\mathrm{t}$} & \multirow[b]{2}{*}{ Sig. } \\
\hline & & $\mathrm{B}$ & Std. Error & & & \\
\hline 1 & (Constant) & 3.395 & .805 & & 4.218 & .000 \\
\hline
\end{tabular}




\begin{tabular}{ll|l|l|l|l}
\hline $\mathrm{X} 1$ & -.026 & .024 & -.114 & -1.087 & .280 \\
\hline $\mathrm{X} 2$ & -.035 & .021 & -.176 & -1.685 & .095 \\
\hline
\end{tabular}

\section{Uji Hipotesis}

Analisis Regresi Linier Berganda

\section{Coefficients $^{\mathrm{a}}$}

Tabel 11. Hasil Uji Regresi Berganda Coefficients

\begin{tabular}{|c|c|c|c|c|c|c|}
\hline \multirow[b]{2}{*}{ Model } & & \multicolumn{2}{|c|}{ Unstandardized Coefficients } & \multirow{2}{*}{$\begin{array}{l}\text { Standardized } \\
\text { Coefficients } \\
\text { Beta }\end{array}$} & \multirow[b]{2}{*}{$t$} & \multirow[b]{2}{*}{ Sig. } \\
\hline & & $B$ & Std. Error & & & \\
\hline \multirow[t]{3}{*}{1} & (Constant) & -2.215 & 1.294 & & -1.712 & .090 \\
\hline & $\mathrm{X} 1$ & .302 & .041 & .534 & 7.311 & .000 \\
\hline & $\mathrm{X} 2$ & .168 & .034 & .356 & 4.867 & .000 \\
\hline
\end{tabular}

\section{Coefficients $^{a}$}

Tabel 12. Hasil Uji Parsial (Uji T) Coefficientsa

\begin{tabular}{|c|c|c|c|c|c|c|}
\hline \multirow[b]{2}{*}{ Model } & & \multicolumn{2}{|c|}{ Unstandardized Coefficients } & \multirow{2}{*}{$\begin{array}{l}\text { Standardized } \\
\text { Coefficients } \\
\text { Beta }\end{array}$} & \multirow[b]{2}{*}{$\mathrm{t}$} & \multirow[b]{2}{*}{ Sig. } \\
\hline & & $\mathrm{B}$ & Std. Error & & & \\
\hline \multirow[t]{3}{*}{1} & (Constant) & -2.215 & 1.294 & & -1.712 & .090 \\
\hline & $\mathrm{X} 1$ & .302 & .041 & .534 & 7.311 & .000 \\
\hline & $\mathrm{X} 2$ & .168 & .034 & .356 & 4.867 & .000 \\
\hline
\end{tabular}

Uji F

Hasil uji F sebagai berikut :

$\mathrm{H}_{0}$ : Tidak ada pengaruh secara simultan dan signifikan antara disiplin dalam tata tertib perusahaan dan disiplin dalam tanggung jawab pada pekerjaan terhadap produktivitas kerja.

$\mathrm{H}_{1}$ : Ada pengaruh secara simultan dan signifikan antara disiplin dalam tata tertib perusahaan dan disiplin dalam tanggung jawab pada pekerjaan terhadap produktivitas kerja.

Tabel 13. Hasil Uji Simultan (Uji F)

ANOVA $^{\mathrm{a}}$

\begin{tabular}{llll|l|l|l|l} 
Model & & $\begin{array}{l}\text { Sum } \\
\text { Squares }\end{array}$ & of & df & Mean Square & F & Sig. \\
\hline 1 & Regression & 361.694 & 2 & 180.847 & 60.688 & $.000^{\mathrm{b}}$ \\
\cline { 2 - 8 } & Residual & 289.056 & 97 & 2.980 & & \\
\cline { 2 - 7 } & Total & 650.750 & 99 & & & \\
\hline
\end{tabular}

\section{Koefesien Determinasi RR^2}

Tabel 14. Koefisien Determinasi Model Summary

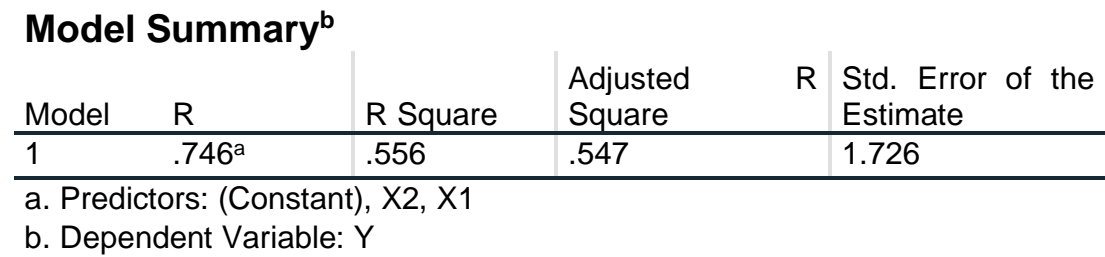

Berdasarkan tabel diatas, dapat dilihat bahwa angka koefisien korelasi ( $\mathrm{R}$ ) sebesar 0,556. Hal ini berarti hubungan antar variabel independen dengan variabel dependen diketahui sebesar $55,6 \%$. Dari angka tersebut dapat diambil kesimpulan bahwa hubungan antara variabel independen 
dengan variabel dependen adalah kuat. Artinya bahwa variabel disiplin dalam tata tertib perusahaan $\left(\mathrm{X}_{1}\right)$ dan variabel disiplin dalam tanggung jawab pada pekerjaan $\left(\mathrm{X}_{2}\right)$ secara simultan (bersama-sama) berpengaruh terhadap variabel produktivitas kerja (Y) sebesar 55,6\%. Sedangkan sisanya $(100 \%$ $55,6 \%=44,4)$ dipengaruhi oleh variabel lain diluar persamaan regresi ini atau variabel yang tidak diteliti.

\section{KESIMPULAN} berikut:

Berdasarkan analisis data dan pembahasan hasil penelitian, dapat ditarik kesimpulan sebagai

Hasil pengujian pada (Uji T) antara variabel disiplin dalam tata tertib perusahaan $\left(\mathrm{X}_{1}\right)$ dengan variabel produktivitas kerja $(\mathrm{Y})$ diperoleh nilai signifikasi sebesar $0,00<0,05$. Dengan nilai t-hitung $>$ t-tabel $(7.311>1,98447)$. Maka dapat disimpulkan bahwa disiplin dalam tata tertib perusahaan berpengaruh secara parsial dan $\mathrm{H} 0$ ditolak dan $\mathrm{H}_{1}$ diterima.

Hasil pengujian pada (Uji T) antara variabel disiplin dalam tanggung jawab pada pekerjaan dengan variabel produktivitas kerja diperoleh nilai signifikasi sebesar $0,00<0,05$. Dan dengan nilai thitung > t-tabel $(4.867>1,98447)$. Maka dapat disimpulkan bahwa disiplin dalam tanggung jawab pada pekerjaan berpengaruh secara parsial dan $\mathrm{H}_{0}$ ditolak dan $\mathrm{H}_{1}$ diterima

Hasil pengujian (Uji F) pada disiplin dalam tata tertib perusahaan dan disiplin dalam tanggung jawab pada pekerjaan berpengaruh positif dan signifikan terhadap produktivitas kerja. Dibuktikan dalam analisis (Uji F) diperoleh nilai signifikasi $0,00<0,05$ dan nilai f-hitung $>\mathrm{f}$-tabel (60.688 > 3.09). Dengan demikian dapat disimpulkan bahwa $\mathrm{H}_{0}$ ditolak dan $\mathrm{H}_{1}$ diterima, yang berarti disiplin dalam tata tertib perusahaan dan disiplin dalam tanggung jawab pada pekerjaan berpengaruh secara simultan dan signifikan terhadap produktivitas kerja di PT. Kawai Piano Indonesia.

\section{DAFTAR PUSTAKA}

Ghozali, I (2018). Apkikasi Analisis Multivariate dengan Program IBM SPSS 25. Semarang: Badan Penerbitan Universitas Diponegoro.

Ghozali, I. (2011). Apkikasi Analisis Multivariate dengan Program SPSS. Semarang: Badan Penerbitan Universitas Diponegoro.

Hasbullah, Rahmat, (2016), Mengelola Perilaku Dalam Organisasi: Tantangan dan Peluang, Cetakan Pertama, Badan Penerbit Fakultas Ekonomi dan Bisnis Unsika.

Hasibuan, Malayu S.P, (2011). Manajemen: Dasar, Pengertian, dan Masalah, Edisi Revisi, PT Bumi Aksara.

Sinungan, Muchdarsyah, (2007). Produktivitas Apa dan Bagaimana, Penerbit Bumi Kasara, Jakarta. Sugiyono. (2008). Metode Penelitian Bisnis. Bandung, Alfa Beta

Sugiyono. (2012). Metode Penelitian Kuantitatif Kualitatif dan R\&D. Bandung: Alfabeta 